\title{
PEMBUATAN BAKSO DARI DAGING IKAN TONGKOL (Euthynnus Affinis)
}

\section{MAKING MEATBALLS FROM TUNA FISH (Euthynnus Affinis)}

\author{
Seriana Zamili*, Mareti Hulu, Irmawati, Sri Fitriyani Sihombing \\ Universitas Islam Sumatera Utara, Department of Chemistry Education, Medan 20217, \\ North Sumatera, Indonesia \\ *Corresponding author : serianazamili44@gmail.com
}

\begin{abstract}
ABSTRAK
Bakso adalah salah satu jenis makanan yang banyak disukai oleh masyarakat luas. Bakso dalam penelitian ini adalah bakso dari ikan tongkol dengan menggunakan daging merah dan daging putih dengan perbandingan tepung $50 \%, 70 \%$ dan $80 \%$. Penelitian ini bertujuan untuk mengetahui mutu bakso yang lebih disukai oleh responden antara bakso ikan tongkol yang menggunakan daging putih dan bakso ikan tongkol yang menggunakan daging merah dengan variasi perbandingan tepung yang sama antara bakso dengan menggunakan daging putih dan bakso dengan menggunakan daging merah. Bakso yang telah dihasilkan dianalisis secara kualitatif yaitu berdasarkan uji organoleptik meliputi uji rasa, aroma, warna dan tekstur. Hasil penelitian bahwa jenis daging pada ikan tongkol yaitu daging merah dan daging putih mempengaruhi rasa, warna dan tekstur pada bakso serta perbandingan tepung dengan daging banyaknya daging ikan, dimana bakso dengan daging putih dan perbandingan tepung $70 \%$ diperoleh data responden yaitu uji organoleptik rasa $80 \%$, aroma $90 \%$, warna $100 \%$ dan tekstur $100 \%$.
\end{abstract}

Kata Kunci : bakso ikan, daging putih ikan tongkol, daging merah ikan tongkol

\begin{abstract}
Meatballs are one type of food that is widely liked by the wider community. Meatballs in this study were meatballs from fish tuna with of flour $50 \%, 70 \%$ and $80 \%$. This study aims to determine the quality of meatballs preferred by respondents between tuna meatballs that use white meat and tuna meatballs that use red meat with the same ratio of flour. The meatballs that have been produced are analyzed qualitatively, which is based on organoleptic tests including tests of taste, fragrance test, color and texture. The results of the study that the type of meat in tuna affected the taste, color and texture of meatballs and the of flour to tuna fish meat was $70 \%$ meatballs obtained by respondens taste $80 \%$, fragrance $90 \%$, color $100 \%$ and texture $100 \%$.
\end{abstract}

Keywords : fish meatballs, white meat tuna, red meat tuna 


\section{PENDAHULUAN}

Bakso merupakan makanan yang sudah dikenal baik dikalangan masyarakat luas. Selain karena rasanya yang enak dan gurih, juga karena makanan ini banyak ditemukan. Bakso yang mudah ditemukan adalah bakso dari daging sapi, bakso ayam yang ditambah dengan bahan tambahan makanan seperti tepung tapioka, bawang merah, bawang putih, serta bahan perasa lainnya yang kemudian dibentuk bulatbulat dan dilakukan perebusan sampai bola-bola bakso mengapung sebagai tanda bakso telah matang (Bakar dan Usmati,2007).

Dikalangan masyarakat selain bakso dari daging sapi, daging ayam juga terdapat bakso ikan. Selama ini masyarakat membuat bakso dari ikan tenggiring, ikan nila yg tergolong mahal. Bakso yang terbuat dari ikan tongkol (Euthynnus Affinis). belum ada ditemukan dalam jajanan masyarakat padahal ikan tongkol merupakan ikan yang tergolong murah dan merupakan ikan produksi terbanyak di daerah Sumatera khususnya.

Ikan tongkol merupakan salah satu ikan yang memiliki kandungan protein yang tinggi yaitu 26,2 $\% / 100 \mathrm{~g}$ dengan kandungan lemak yang rendah $1 \% / 100 \mathrm{~g}$, dan sangat cocok dikonsumsi oleh anak-anak pada masa pertumbuhan, selain itu ikan tongkol juga sangat kaya akan kandungan asam lemak omega-3 (Sanger 2010). Berdasarkan jenis daging, ikan tongkol memiliki daging merah dengan kandungan air $66,7 \% / 100 \mathrm{~g}$, protein $27,6 \% / 100 \mathrm{~g}$, dan lemak 2,6\%/100g dan daging putih dengan kandungan air 67,1\%/100g, protein 31\%/100g dan lemak 0,7\%/100g. Astuti. 2009)

Pada penelitian ini yaitu tentang pembuatan bakso dari ikan tongkol akan dilakukan berdasarkan perbedaan daging merah dan daging putih pada ikan tongkol (Euthynnus Affinis) serta dengan perbandingan tepung yaitu $30 \%, 50 \%$ dan $70 \%$.

\section{METODE PENELITIAN}

\subsection{Jenis Penelitian}

Jenis penelitian ini adalah penelitian eksperimental. Penelitian ini dilakukan sebnyak 3 variasi yaitu $30 \%, 50 \%$ dan $70 \%$.

\subsection{Waktu dan Tempat Penelitian}

Penelitian ini dilaksanakan pada bulan april 2019 hingga bulan mei 2019 dan tempat penelitian dilaksanakan di Laboratorium Kimia FKIP UISU.

\subsection{Target / Subjek Penelitian}

Parameter yang diuji adalah uji organoleptik meliputi aroma, rasa, tekstur dan warna dengan menggunakan metode Kuisioner.

\subsection{Prosedur}

Tahap 1. Penghalusan bahan bakso diawali dengan pemotongan daging ikan yaitu daging ikan tongkol (Euthynnus Affinis) dipotong kecil-kecil kemudian di blender dengan ditambahkan bawang merah, bawang putih, merica bubuk, garam serta air es. 
Tahap 2. Pembuatan adonan bakso yaitu bahan yang sudah di haluskan ditambahkan tepung tapioka dengan 3 variasi yaitu 50\%, 70\% dan 80\% serta dengan penambahan Sodium Tripoli Fosfat (STF) sebagai bahan penyenyal pada bakso.

Tahap 3. Pembentukan bola-bola bakso dengan memamkai tangan atau pun sendok dan dilanjutkan dengan perebusan bola-bola bakso hinnga masak yang ditandai dengan mengapungnya bola-bola bakso diatas permukaan air rebusan bakso.

Tahap 4. Dialkukan pengujian membagikan bakso-bakso kepada responden kemudian mengisi kuisioner uji organoliptik yang meliputi rasa, aroma, warna dan tekstur.

\subsection{Teknik Pengumpulan Data}

Metode yang dilakukan adalah metode eksperimen. Melalui metode ini peneliti memperoleh data dengan melakukan percobaan secara langsung.

\subsection{Teknik Analisis Data}

Data hasil penelitian dianalisis dengan metode deskriptif kualitatif yaitu menjelaskan hasil uji organoleptik meliputi rasa, tekstur, warna dan aroma serta kekenyalan antara 3 variasi yaitu 50\%, 70\% dan $80 \%$ serta antara perbedaan daging merah dan daging putih pada ikan tongkol (Euthynnus Affinis).

\section{HASIL DAN PEMBAHASAN}

\subsection{Data pengamatan}

Penilaian organoleptik dilakukan dengan menggunakan 10 0rang responden yang telah mencoba mencicipi bakso yang telah di buat oleh peneliti dengan 3 variasi yaitu $30 \%, 50 \%, 80 \%$ meliputi rasa, aroma tekstur warna dan kekenyalan dapat dilihat pada tabel berikut :

Tabel 1. Uji Organoleptik Bakso Ikan Tongkol Dengan Daging Putih

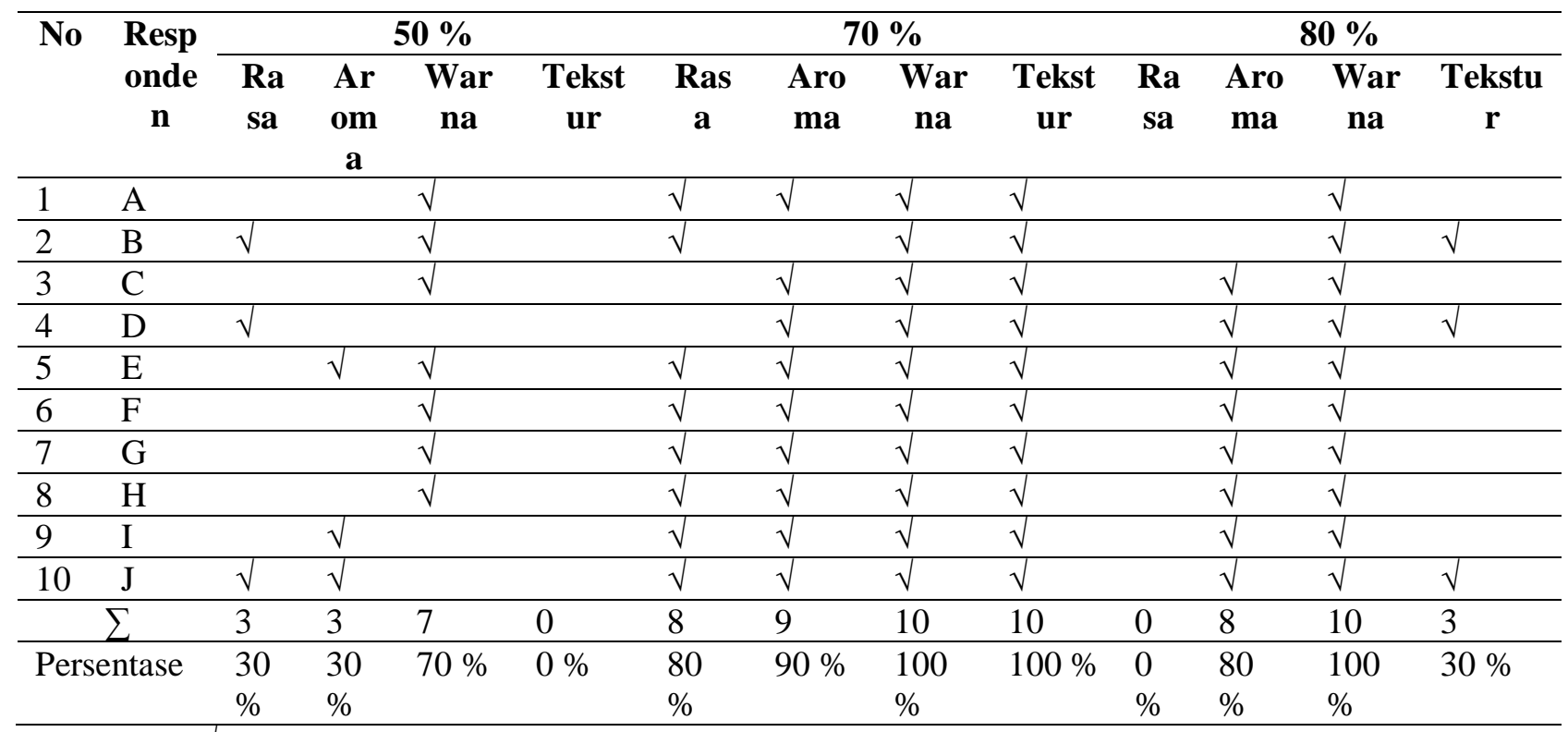

Keterantan $\sqrt{ }=$ Suka 
Tabel 2. Uji Organoleptik Bakso Ikan Tongkol Dengan Daging Putih

\begin{tabular}{|c|c|c|c|c|c|c|c|c|c|c|c|c|c|}
\hline \multirow[t]{2}{*}{ No } & \multirow{2}{*}{$\begin{array}{c}\text { Resp } \\
\text { onde } \\
\text { n }\end{array}$} & \multicolumn{4}{|c|}{$50 \%$} & \multicolumn{4}{|c|}{$70 \%$} & \multicolumn{4}{|c|}{$80 \%$} \\
\hline & & $\begin{array}{c}\text { Ra } \\
\text { sa }\end{array}$ & $\begin{array}{c}\mathbf{A r} \\
\text { om } \\
\mathbf{a}\end{array}$ & $\begin{array}{c}\text { War } \\
\text { na }\end{array}$ & $\begin{array}{c}\text { Tekst } \\
\text { ur }\end{array}$ & $\begin{array}{c}\text { Ras } \\
\mathbf{a}\end{array}$ & $\begin{array}{c}\text { Aro } \\
\text { ma }\end{array}$ & $\begin{array}{c}\text { War } \\
\text { na }\end{array}$ & $\begin{array}{c}\text { Tekst } \\
\text { ur }\end{array}$ & $\begin{array}{c}\mathbf{R a} \\
\mathbf{S a}\end{array}$ & $\begin{array}{c}\text { Aro } \\
\text { ma }\end{array}$ & $\begin{array}{c}\text { War } \\
\text { na }\end{array}$ & $\begin{array}{c}\text { Tekstu } \\
\mathbf{r}\end{array}$ \\
\hline 1 & $\mathrm{~A}$ & & & & & & $\sqrt{ }$ & & $\sqrt{ }$ & & & $\sqrt{ }$ & \\
\hline 2 & B & & & & & $\sqrt{ }$ & & $\sqrt{ }$ & $\sqrt{ }$ & & & $\sqrt{ }$ & $\sqrt{ }$ \\
\hline 3 & $\bar{C}$ & & & $\sqrt{ }$ & & & $\sqrt{ }$ & & $\sqrt{ }$ & & $\sqrt{ }$ & & \\
\hline 4 & $\mathrm{D}$ & & & & & & $\sqrt{ }$ & & $\sqrt{ }$ & & $\sqrt{ }$ & $\sqrt{ }$ & $\sqrt{ }$ \\
\hline 5 & $\mathrm{E}$ & & $\sqrt{ }$ & & & $\sqrt{ }$ & $\sqrt{ }$ & & & & $\sqrt{ }$ & & \\
\hline 6 & $\mathrm{~F}$ & & & $\sqrt{ }$ & & & $\sqrt{ }$ & $\sqrt{ }$ & $\sqrt{ }$ & & $\sqrt{ }$ & & \\
\hline 7 & $\mathrm{G}$ & & & & & & $\sqrt{ }$ & & & & $\sqrt{ }$ & $\sqrt{ }$ & \\
\hline 8 & $\mathrm{H}$ & & & $\sqrt{ }$ & & $\sqrt{ }$ & $\sqrt{ }$ & & $\sqrt{ }$ & & $\sqrt{ }$ & $\sqrt{ }$ & \\
\hline 9 & I & & $\sqrt{ }$ & & & & $\sqrt{ }$ & $\sqrt{ }$ & $\sqrt{ }$ & & $\sqrt{ }$ & & \\
\hline 10 & $\mathrm{~J}$ & $\sqrt{ }$ & $\sqrt{ }$ & & & $\sqrt{ }$ & $\sqrt{ }$ & $\sqrt{ }$ & $\sqrt{ }$ & & $\sqrt{ }$ & $\sqrt{ }$ & $\sqrt{ }$ \\
\hline & $\sum$ & 1 & 3 & 3 & 0 & 4 & 9 & 4 & 8 & 0 & 8 & 6 & 3 \\
\hline & entase & $\begin{array}{l}10 \\
\%\end{array}$ & $\begin{array}{l}30 \\
\%\end{array}$ & $30 \%$ & $0 \%$ & $\begin{array}{l}40 \\
\%\end{array}$ & $90 \%$ & $40 \%$ & $80 \%$ & $\begin{array}{l}0 \\
\%\end{array}$ & $\begin{array}{l}80 \\
\%\end{array}$ & $60 \%$ & $30 \%$ \\
\hline
\end{tabular}

Keterantan $\sqrt{ }=$ Suka

\subsection{Pembahasan}

Berdasarkan hasil uji mutu organoleptik terhadap rasa bakso ikan tongkol dengan menggunakan daging putih dengan perbandingan tepung 50\%, $70 \%$ dan $80 \%$ berturut-turut $30 \%, 80 \%$ dan $0 \%$ sedangkan uji organoleptik terhadap bakso ikan tongkol dengan daging merah berturut-turut adalah dengan perbandingan tepung $50 \%, 70 \%$ dan $80 \%$ berturut-turut $10 \%, 40 \%$ dan $0 \%$ dengan responden sebanyak 10 orang. Berdasarkan uji organoleptik, responden lebih menyukai rasa bakso ikan tongkol dengan menggunakan daging putih pada perbandingan tepung $70 \%$.

Pada uji organoleptik aroma terhadap bakso ikan tongkol dengan menggunakan daging putih dalam 3 variasi perbandingan jumlah tepung yaitu 50\%, $70 \%$, dan $80 \%$ berturut-turut $30 \%, 90 \%$ dan $80 \%$ sedangkan pada bakso ikan tongkol dengan menggunakan daging putih dengan variasi yang sama berturut=turut $30 \%, 90 \%$ dan $0 \%$. Pada uji organoleptik aroma terhadap kedua jenis bakso tersebut dengan variasi perbandingan tepung yang sama responden lebih menyukai bakso ikan tongkol dengan menggunakan daging putih saja pada perbandingan tepung $70 \%$.

Berdasarkan uji organoleptik terhadap bakso ikan tongkol dengan menggunakan daging putih dalam 3 variasi perbandingan tepung yaitu 30\%, 70\% dan $80 \%$ berturut-turut $70 \%, 100 \%$, dan $100 \%$ sedangkan pada bakso ikan tongkol dengan menggunakan daging merah dengan variasi yang sama berturut-turut $30 \%$, 40\% dan 60\%. Berdasarkan uji organoleptik terhadap warna, responden lebih menyukai ikan tongkol dengan menggunakan daging putih pada perbandingan tepung $70 \%$.

Berdasarkan ujiorganoleptik terhadap tekstur bakso ikan tongkol menggunkan daging putih dengan variasi perbandingan tepung $50 \%, 70 \%$ dan $80 \%$ berturut-turut $0 \%, 100 \%$ dan $30 \%$ sedangkan pada bakso ikan dengan menggunakan daging merah dengan variasi perbandingan tepung $50 \%, 70 \%$ dan $80 \%$ berturu-turut $0 \%, 80 \%$ dan 30\%. Berdasarkan tekstur kekenyalan responden lebih menyukai tekstur bakso dengan menggunakan daging putih pad variasi perbandingan tepung $70 \%$. 


\section{SIMPULAN DAN SARAN}

\subsection{Simpulan}

Berdasarkan hasil penelitian dapat disimpulkan bahwa :

1. Daging putih ikan tongkol lebih enak dijadikan bakso dengan penambahan tepung $70 \%$ dibandingkan dengan daging merah pada ikan tongkol.

2. Volume tepung mempengaruhi rasa, tekstur dan aroma pada pembuatan bakso ikan tongkol baik menggunakan daging merah maupun daging putihnya.

\subsection{Saran}

1. Untuk peneliti lanjutan dapat dilaksanakan dengan menggunakan tepung lain selain tepung tapioka untuk mengetahui apakah jenis tepung dapat mempengaruhi mutu bakso.

2. Perlu dilakukan pengujian terhadap kandungan gizi yang terdapat pada bakso ikan tongkol.

\section{DAFTAR PUSTAKA}

Astuti, E. 2009. Pengaruh Jenis Tepung Dan Cara Pemasakan Terhadap Mutu Bakso Dari Surimi Ikan Hasil Tangkapan Sampingan (HTS). Skripsi. Program Studi Teknologi Hasil Pertanian, Fakultas Perikanan dan Kelautan. Institut Pertanian Bogor.

Bakar, A. dan Usmati S. 2007. Teknologi Pengolahan Daging. Bogor : Balai Besar Penelitian dan Pengembangan Pasca Panen Pertanian.

Wibowo, S. 2004. Pembuatan Bakso Ikan dan Bakso Daging. Penebar Swadaya. Jakarta. 